\title{
Narracyjna i nienarracyjna koncepcja dyskursu literaturoznawczego
}

\begin{abstract}
Ulicka Danuta, Narracyina i nienarracyina koncepcja dyskursu literaturoznawczego [The narrative and non-narrative conception of discourse of literary studies]. "Przestrzenie Teorii" 3/4, Poznań 2004, Adam Mickiewicz University Press, pp. 21-42. ISBN 83-232-1454-9. ISSN $1644-6763$.
\end{abstract}

The article addresses questions of the relation between literary and literary science discourse which have been intensively discussed in poststructuralist reflection. As the author argues, their separation, accepted until the half of the century, in fact took place on the basis of pragmatic criteria (strongly connected with institutional division of work in the field of literary sciences), and not of a statement's formal characteristics or reference. What created the effect of stylistic, generic and compositional distinctness of speech genres inherent to literary science was only the prototype of literary science discourse shaped in result of their application and frequently confirmed in normative approaches, where it was formulated in terms of the categories of "truth" obliging science, as opposed to "fiction" distinguishing literature. Yet ineffaceable differences between literature and literary science are related to non-fictional and principally monosubjective characteristics of the discourse of the latter. Hence, in opposition to currently dominating narrativist interpretations, they can be by no means identified with respect to the "narrativeness" recognizable in both cases. While discussing these approaches on the basis of three chosen Polish works belonging to historioliterary prose, the author proposes to treat literary science discourse in categories applied to the description of a dramatic statement. For, what seems to be of paramount importance both in modernist and postmodernist phase, is the question of the author's subject's position and attitude towards the object of the statement and the relevant modalization of speech. A detailed analysis of their historical changeability remains, however, beyond the scope of the presented considerations.

W odróżnieniu od tej dziwnej instytucji zwanej literaturą, w tej dziwnej instytucji zwanej jej teorią nie można wprawdzie powiedzieć wszystkiego, ale - podobnie jak w literaturze - można mówić w dowolny sposób1 ${ }^{1}$ Granice swobody kształtowania wypowiedzi są w niej względne i zmienne; wyznacza je historycznie niestały, choć czasowo i lokalnie

1 Trawestując tytuł znanego wywiadu przeprowadzonego $\mathrm{z}$ J. Derridą przez D. Attridge'a Ta dziwna instytucja zwana literaturą (przekład polski M. P. Markowskiego, „Literatura na Świecie" 1998, nr 11-12; przedr. w: Dekonstrukcja w badaniach literackich, red. R. Nycz, Gdańsk 2000), odsyłam do jego wypowiedzi, sformułowanych w tej rozmowie bardziej otwarcie niż w innych tekstach, na temat możliwości rozgraniczenia literatury od innych typów pisarstwa, wskazujących na (1) niemożnośc ich rozdzielenia, ale też (2) trwałość podejmowanych $w$ tym kierunku wysiłków i nieusuwalnosć przekonań o ich odmienności. Przekonania te zdają się formułować reguły praktyki pisarskiej samego Derridy. 
stabilizowany - przynajmniej od 2. połowy XIX wieku - zinstytucjonalizowany układ odniesienia. Najważniejszą rolę odgrywają w nim prototy$\mathrm{py}^{2}$ dyskursów literackiego i literaturoznawczego (naukowego). Ten ostatni, utrwalony w (również profesjonalnej) świadomości potocznej jako tzw. folk science ${ }^{3}$, rozstrzyga o aktualnej kategoryzacji (rozgraniczaniu, „mapowaniu”) pola dyskursywnego. Centrum prototypu wyznacza przedmiot i tryb, w jaki ustosunkowuje się do niego podmiot. Tryb ten wyraża się historycznie i kulturowo utrwalonymi gatunkami mowy literaturoznawczej4. Ich repertuar, podobnie jak repertuar gatunków mowy $w$ innych sferach porozumiewania się, jest nieograniczony; restrykcje, regulujące komunikację wspólnoty literaturoznawczej, mają genealogię historyczno-kulturową i środowiskową.

Przedmiot dyskursu literaturoznawczego ma status obiektu wtórnie intencjonalnego ${ }^{5}$, uprzedniego (pomimo wszystko) wobec wszelkich poznawczych działań podmiotu, obojętne - analitycznych czy interpretacyjnych, rekonstrukcyjnych czy konstrukcyjnych. Jest „dany” i dopiero dzięki temu „zadany”. To przede wszystkim różni go od przedmiotu dyskursu literackiego. W literaturoznawstwie, nie inaczej niż $w$ innych dziedzinach nauk o kulturze, podmiot i przedmiot pozostają wobec siebie "obcy", jakkolwiek silne byłoby ich wzajemne uwikłanie i jakkolwiek mocno od działań podmiotu zależałaby (re)kreacja przedmiotu ${ }^{6}$. Pierwot-

2 „Prototyp” rozumiem, jak większość literaturoznawców, nie za E. Rosch, lecz Ch. Taylorem, Linguistic Categorization. Prototypes in Linguistic Theory, Oxford 1995; [wyd. I: 1989] Kategoryzacja $w$ języku. Prototyp $w$ teorii językoznawczej, przeł. A. Skucińska, Kraków 2001.

${ }^{3} \mathrm{O}$ folk-science, tj. utrwalonych wyobrażeniach o nauce, pisał J. Bruner w Acts of Meaning, Cambridge Mass. 1990, nawiązując do tzw. folk-psychology, tj. potocznych przekonań o możliwości rozumienia innych ludzi powielanych w koncepcjach pretendujących do miana wiedzy (szerzej na ten temat: J. Płuciennik, Literackie identyfikacje $i$ oddźwięki. Poetyka a empatia, Lódź 2002).

${ }^{4}$ Pojęcia gatunku mowy używam za M. Bachtinem (M. Bachtin, Problem gatunków mowy, w: tegoż, Estetyka twórczości stownej, przeł. D. Ulicka, Warszawa 1986) oraz ujęciami inspirowanymi jego teorią, łączącymi ją z koncepcją illokucji J. L. Austina i gier językowych L. Wittgensteina, i wyprowadzającymi z tych źródeł tzw. nową genologię lub generologię. Por. B. Witosz, Gatunek - sporny (?) problem wspótczesnej refleksji tekstologicznej, w: Sporne i bezsporne problemy wspótczesnej wiedzy o literaturze, red. W. Bolecki i R. Nycz, Warszawa 2002.

5 Tę ontologiczną charakterystykę zapożyczam od R. Ingardena; fenomenolog rozwinąl ją, opisując sposób istnienia dzieła literackiego, tzn. wszelkiego wytworu językowego, nie zaś tylko - wbrew rozpowszechnionym interpretacjom - literackiego dzieła sztuki, potocznie kojarzonego z literaturą wyróżnioną przez wartość estetyczną.

${ }^{6}$ Polemizuje tu $\mathrm{z}$ przekonaniami konstruktywistycznymi, reprezentowanymi na gruncie literaturoznawstwa przez zwolenników tzw. zwrotu interpretacyjnego. W nauce o literaturze polskiej najmocniej wyraził je A. Szahaj w artykule Granice anarchizmu interpretacyjnego, „Teksty Drugie” 1997, nr 6, wspierając się na autorytetach R. Rorty’ego 
ność obiektu wobec subiektu decyduje jednak tylko o ograniczeniu swobody manewrów poznawczych - ale nie dyskursywnych. Granice wolności dyskursywnej w literaturoznawstwie wiążą się natomiast $\mathrm{z}$ niefikcjonalnością i jednopodmiotowością używanych w nim wypowiedzi. Tego ich charakteru nie zmienia ani jej (możliwa) fikcyjność, ani możliwa wewnętrzna wielogłosowość, ani przypisywana (postulowana) modalność ${ }^{7}$. Wypowiedź może mieć charakter asertoryczny, wyrażający przekonanie o pewności stwierdzeń, ale może też przyjmować charakter aletyczny, możliwościowy (wyrażający się $\mathrm{w}$ przypuszczeniach i nawet zdaniach kontrfaktycznych), charakter epistemiczny bądź deontyczny. Repertuar rozpoznawanych $w$ logice odmian modalności nie wyczerpuje tych, jakie dadzą się wyróżnić w literaturoznawstwie, sygnalizuje jednak przynajmniej, że przynależny jest mu nie tylko tryb związany z funkcją poznawczą; może ono być nastawione także perswazyjnie, np. ideologicznie bądź etycznie albo konfesyjnie. Reprezentacją podmiotowych intencji są właśnie literaturoznawcze gatunki mowy i zrośnięty z nimi sposób kształtowania wypowiedzi.

Są to, jeśli nie jedyne, to najważniejsze ograniczenia wiążące dyskurs o literaturze i decydujące o jego tożsamości, tzn. przede wszystkim - lokalnej i czasowej odmienności od dyskursu literackiego. Historyczny przegląd odmian wypowiedzi uznawanych w kulturze (europejskiej) za literaturoznawcze dowodzi, że nie musi ona respektować żadnych bodaj wymagań związanych $z$ językiem i stylem, sposobem prowadzenia narracji i jej kompozycją (porządkiem argumentacji) ani ksztattem gatunkowym. Poszukiwania syntaktycznych kryteriów typologicznych są, podobnie jak próby podejmowane dla dyskursu literackiego, bezowocne; nie ma - by strawestować znanego badacza aktów mowy - żadnej takiej właściwości, syntaktycznej, stylistycznej bądź kompozycyjnej, która by odróżniała tekst literacki od literaturoznawczego ${ }^{8}$. Decydującą rolę należy przyznać raczej kryteriom pragmatycznym. Modalizatory wypowiedzi naukowej (jej językowo-stylistyczne wykładniki bądź tzw. wskaźniki

i S. E. Fisha (por. tez jego wykładnię poglądów Fisha, Nie ma niczego poza interpretacjq, tako rzecze Stanley Fish,, „Er|rlgo" 2001, nr 2). Fish jednak - warto dodać - w ostatnich książkach (Professional Correctnes: Literary Studies and Political Change, Oxford 1995 i How Milton Works, Cambridge 2001) zdecydowanie wycofał się z "twardego" konstruktywizmu, powracając do poglądów głoszonych na początku swoich poszukiwań, bliższych reader-response criticism, jesli wręcz nie tradycyjnej, filologicznie nastawionej historii literatury.

${ }^{7} \mathrm{O}$ modalności jako kategorii literaturoznawczej patrz W. Bolecki, Modalność ( $L i$ teraturoznawstwo $i$ kognitywizm. Rekonesans), w: Sporne i bezsporne problemy wspótczesnej wiedzy o literaturze, o tzw. modalizatorach - J. Płuciennik, op. cit.

8 J. R. Se arle, Status logiczny wypowiedzi fikcyjnej, przeł. H. Buczyńska-Garewicz, „Pamiętnik Literacki” 1980, z. 2. 
performatywne) są zmienne i wynikają zarówno $\mathrm{z}$ określonych koncepcji wiedzy, jak $z$ dominującej $w$ danym układzie odniesienia koncepcji literatury. Pod tym względem sytuacja literaturoznawstwa nie jest zresztą zasadniczo odmienna od innych dyscyplin w obszarze nauk o kulturze, tych zwłaszcza, które mają do czynienia z tekstami utrwalonymi w języku naturalnym (stąd trudność i umowność kwalifikowania wielu wypowiedzi do nauki bądź literatury, z drugiej zaś strony ich przyłączania do instytucjonalnie wydzielanych dyscyplin - literaturoznawstwa, filozofii, antropologii, psychologii, socjologii czy kulturoznawstwa, a w obrębie samego literaturoznawstwa - poetyki, retoryki, komparatystyki, historii czy teorii literatury bądź krytyki literackiej).

Do rozpoznania względności i historycznej zmienności wykładników dyskursu literaturoznawczego i literackiego, a zatem niemożności ich absolutnego rozgraniczenia, szczególnie silnie przyczyniła się refleksja poststrukturalistyczna, inspirowana kolejno przez zwroty: lingwistyczny, narratywistyczny, interpretacjonistyczny, retoryczny, kontekstualistyczny (kulturalistyczny) i etyczny, oraz, mniej eksponowana i eksploatowana, tzw. druga rewolucja kognitywistyczna ${ }^{9}$. W efekcie analiz prowadzonych w horyzoncie tych „zwrotów” i ,rewolucji” w różnych dyscyplinach wiedzy o kulturze, zdiagnozowana została szczególna i uznawana za symptomatyczną dla fazy postmodernistycznej sytuacja „zagłady” bądź „zmącenia” gatunków (należałoby raczej powiedzieć: dyskursów), zarówno naukowych, jak literackich, ich wymieszania, splątania, „hybrydyczności”10. Ich „nieostrość"11 wiązano także $\mathrm{z}$ nieokreślonym statusem przedmiotu referencji oraz niejednoznacznym nastawieniem podmiotu. Ten stan rzeczy zaświadczać miał o utraconej wraz z końcem modernizmu tożsamości literaturoznawstwa.

9 Włączam propozycje kognitywistyczne z kręgu N. Chomsky'ego do jednego szeregu z projektami zarysowywanymi przez przedstawicieli wymienionych „zwrotów”, choć wspierają się one na diametralnie odmiennych koncepcjach języka i znaczenia, gdyż mimo tej zasadniczej różnicy w wielu miejscach pokrywają się one ze sobą (szczególnie silne zależności zachodzą np. między przekonaniami kognitywistów i przedstawicieli „zwrotu retorycznego" i konstruktywizmu, tak że niekiedy klasycy kognitywistycznej refleksji o znaczeniu, M. Turner i G. Lakoff, są uznawani za konstruktywistów). O związkach między narratologią i kognitywizmem patrz: E. Ibsch, The Cognitive Turn in Narratology, „Poetics Today" 1990, vol. 11, nr 2.

${ }^{10}$ Por. S. Balbus, Zagłada gatunków, w: Genologia dzisiaj, red. W. Bolecki i I. Opacki, Warszawa 2000; C. Geertz, O gatunkach zmqconych (Nowe konfiguracje myśli społecznej), przeł. Z. Lapiński, w: Postmodernizm. Antologia przekladów, red. R. Nycz, Warszawa 1997; G. Grochowski, Tekstowe hybrydy. Literackość i jej pograni$c z a$, Wrocław 2000.

11 O kategorii nieostrości i jej poznawczych uwarunkowaniach patrz: np. prace zebrane w tomie $O$ nieostrości, red. Z. Muszyńska, Lublin 1988; A. Duszak, Tekst nieostry, w: tejże, Tekst, dyskurs, komunikacja międzykulturowa, Warszawa 1998. 
Tymczasem wydaje się, że tracić nie było czego: tożsamość dyskursu naukowego, podobnie jak literackiego, o którą walczyło literaturoznawstwo teoretyczne przez całą 1 . połowę XX wieku, była stanem pożądanym $i$, zwykle normatywnie, projektowanym, a nie rzeczywistym (dobitnie świadczą o tym wciąż w nim ponawiane dyskusje „o tzw. «prawdzie» w literaturze"12 i współczesne przeprowadzki wypowiedzi eseistycznej, autobiograficznej i dokumentalnej z peryferii, a nawet spoza pola literackości do jego centrum), nadto w stosunkowo krótkiej, jeśli myśleć w perspektywie długiego trwania dyscypliny, epizodycznej zgoła, fazie modernizmu ${ }^{13}$. Literaturoznawczy dyskurs, nazywany postmodernistycznym, nie jest pod tym względem odmienny od modernistycznego: w obu postulowana tożsamość/nietożsamość ma charakter relacyjny, a nie bezwzględny'14. Różnią się one jedynie prototypem, decydującym o kategoryzacji, i stopniem absorpcji wypowiedzi o rozmytych wyznacznikach. Prototyp uznawany za postmodernistyczny (tak jak postmodernistyczny prototyp literacki i w ogóle artystyczny) jest pod tym względem znacznie bardziej chłonny i tolerancyjny. Z drugiej strony jest on - tym razem tak jak modernistyczny prototyp literacki - nastawiony na innowacyjność, jednokrotność, przygodność i niestandardowość. Chętniej używa strategii palinodii.

Najważniejsze jednak wydaje się to, że ów stan (nie)utraconej tożsamości, polegający, mówiąc dobitnie, na odstawaniu od relacyjnego prototypu (szczególnie w przypadku dyskursu naukowego, który w refleksji modernistycznej rzadko bywał przedmiotem samodzielnych analiz innych niż normatywne neopozytywistyczno-analityczne, kształtując się jak samorodek, na zasadzie opozycji do drobiazgowo z kolei analizowanego prototypu dyskursu uznawanego za literacki) - że ów stan stwierdzany $\mathrm{w}$ refleksji metanaukowej jako fakt zaistnial $\mathrm{w}$ rezultacie: po pierwsze - wyboru określonego prototypu, po drugie - zaniechania w rozważaniach o różnych typach dyskursu problemu ich odniesienia i ich podmiotowej modalności. Utrwalił się zaś i stał „faktem nauko-

12 Używam zapożyczonej z tytułu rozprawy R. Ingardena „nazwy zbiorowej” dla tych, stanowiących leitmotiv dyskusji z I polowy stulecia, gdyż ona właśnie wyznaczyła ich horyzont.

13 Patrz: R. Nycz, Literatura nowoczesna - cztery dyskursy, „Teksty Drugie” 2002, nr 4.

14 Przychylam się tu do coraz bardziej wpływowych poglądów traktujących postmodernizm jako kolejną fazę rozwojową modernizmu głoszonych m.in. przez G. Graffa, W. Welscha i J.-F. Lyotarda; interesujących argumentów na rzecz takiego ujęcia, podnoszących nie tylko „mit przełomu postmodernistycznego" (jak zatytułował swoje znane wystąpienie Graff, przekład polski G. Cendrowskiej, w: Nowa proza amerykańska. Szkice krytyczne, wybór, oprac. i wstęp Z. Lewicki, Warszawa 1983), ale nawet modernizmu, dostarcza B. Latour, We Have Never Been Modern, New York 1993. 
wym"15, gdy analiza wypowiedzi została zredukowana do poziomu zwanego (myląco, o czym dalej) narracją albo z pominięciem obiektu (jak w nurtach nominalistycznych), albo uznania, że jest to obiekt o naturze tekstowej oraz pozostawienia na uboczu kwestii nastawienia podmiotu. Tak właśnie, jak to najczęściej bywa w analizach narratologicznych, które rozciągnęły wypracowany w literaturoznawstwie strukturalistycznym (rzadziej - również fenomenologiczno-hermeneutycznym) narracyjny model dyskursu i narracyjnej (monologowej) podmiotowości na teren tekstów prototypowo uznawanych za naukowe. Za prototyp narracji w dyskursie naukowym posłużył przy tym dyskurs postulowany w pozytywistycznej i neopozytywistycznej filozofii wiedzy, zakładający normatywnie modalność epistemiczną (jak gdyby do takich wypowiedzi ograniczały się wypowiedzi uznawane w okresie jego dominacji za naukowe), za prototyp narracji w dyskursie literackim uchodził dyskurs zakładający normatywnie modalizację estetyczną wypowiedzi. Oba prototypy, i literacki, i literaturoznawczy (naukowy), łączy jedno: marginalizacja (wyparcie ${ }^{16}$ ) kwestii przedmiotu i podmiotu wypowiedzi.

Inaczej niż w 1. połowie XX wieku, w jego 2. połowie status i specyfika przedmiotu wypowiedzi literaturoznawczej nie ogniskowały uwagi badaczy; skupiała się ona raczej na jej statusie dyskursywnym. Do wymienianych zwykle, „wewnętrznych” przyczyn takiego stanu rzeczy, wskazujących na znużenie uznanymi za bezowocne wysiłkami $z$ poprzedniego okresu i podchwyconą przez badaczy literatury krytyką tzw. myślenia metafizycznego, która narzuciła reinterpretację zasady referencji, dodać by należało przyczyny „zewnętrzne”: zmiany w filozofii wiedzy (Popperowskie podważenie wynikania teorii $\mathrm{z}$ faktów i kontynuującą je, a poświadczoną argumentami z historii wiedzy, Feyerabendowską krytykę rzetelnego, tj. zgodnego $\mathrm{z}$ regułami logiki, dowodzenia), przemiany w filozofii sztuki i w samej sztuce ${ }^{17}$. Przyczyn można wskazać daleko więcej, jednak ważne jest nie ich wyliczenie, lecz efekt. Ten zaś

15 Pojęcia "faktu naukowego" używam w znaczeniu nadanym przez L. Flecka, Powstanie i rozwój faktu naukowego. Wprowadzenie do nauki o stylu myślowym i kolektywie myślowym, przel. z języka niemieckiego M. Tuszkiewicz, wstęp do wydania polskiego Z. Cackowski, Lublin 1986 i rozwijającego jego propozycję T. Kuhna, Struktura rewolucji naukowych, przeł. H. Ostromęcka, Warszawa 2001.

${ }^{16} \mathrm{O}$ zasadności użycia tego zrośniętego z psychoanalizą terminu patrz A. Motycka, Nauka i nieświadomość, Wrocław 1998.

17 Rozstrzygającą rolę w desubstancjalizacji sztuki odegrał, jak się wydaje, informel, ważniejszy pod tym względem niż abstrakcjonizm; interesująco pisze o tym M. Porębski w Desce, Warszawa 1997, s. 165-166. O awangardowych i postawangardowych nurtach „odprzedmiotowiających” w sztukach plastycznych patrz: S. Morawski, Czy zmierzch estetyki?, w: Zmierzch estetyki - rzekomy czy autentyczny?, wybór i wstęp S. Morawski, Warszawa 1987, t. 1. 
sprowadza się do uznania za przedmiot poznania naukowego samego poznania, tyle że rozumianego nie - jak w refleksji krytycznej z 1. połowy wieku XX - jako akt uwarunkowany epistemologiczne, lecz jako jego wytwór - tekst, także uwarunkowany, a nawet zdeterminowany, niezależnymi od podmiotu regułami dyskursywnymi.

Tekst, jeśli nawet nie utożsamiany z samym przedmiotem poznania (,zdarzeniem"), to przynajmniej z jedynym dostępnym badaniu obiektem (,faktem") ${ }^{18}$, stanął w centrum różnych nauk, zarówno o kulturze i społeczeństwie, jak i nawet o naturze (historiografii, psychologii, ekonomii, prawie, etyce, polityce, socjologii, biologii i genetyce $)^{19}$. Niezależnie od

18 W pracach narratologicznych pojęcia „faktu” i „zdarzenia” są używane względnie dowolnie. Tu wprowadzam ich rozróżnienie za $\mathrm{H}$. White'em; por. tegoż, Tekst narracyjny jako artefakt literacki, przel. M. Wilczyński, w: tegoż, Poetyka pisarstwa historycznego, red. E. Domańska i M. Wilczyński, Kraków 2000.

19 Prac wprowadzających koncepcje wypracowane w literaturoznawstwie do różnych dyscyplin wiedzy powstało w ostatnim tylko półwieczu niezmiernie wiele; skomponowanie ich wyczerpującej listy nie wydaje się tu celowe. Podaję tylko te, które odwołują się do teorii literatury jako do autorytetu, który pozwala na zredefiniowanie przedmiotu $\mathrm{z}$ własnej dziedziny badawczej: H. White, Poetyka pisarstwa historycznego; R. H. Brown, A Poetics for Sociology: Toward a Logic of Discovery for the Human Sciences, Cambridge 1977 (fragment z tej pracy, Metafora jako model, opublikowaly „Teksty Drugie” 1980, $\mathrm{nr}$ 6); Writing the Social Text: Poetics and Politics in Social Science Discourse, ed. R. H. Brown, New York 1992; R. Edmondson, Rhetoric in Sociology, London 1984; J. Marias, Philosophy as Dramatic Theory, University Park 1971 (fragment Gatunki literackie $w$ filozofii $w$ przekładzie A. Labudy w „Pamiętniku Literackim” 1979, z. 2); J. Reé, Philosophical Tales: An Essay on Philosophy and Literature, London 1987; A. Benjamin, Philosphy's Literature, Manchester 2001; D. P. Spence, Theories of Mind: Science and Literature, "Poetics Today” 1990, vol. 11. Nr 2; M. Billings, Arguing and Thinking: A Rhetorical Approach to Social Psychology, Cambridge 1987; M. Bowie, Freud, Proust, and Lacan. Theory as Fiction, Cambridge 1987; A. Trzebiński, Narracja jako sposób rozumienia świata, w: Praktyki opowiadania, red. B. Owczarek, Z. Mitosek, W. Grajewski, Kraków 2001; C. Geertz, Dzieto i życie. Antropolog jako autor, przel. E. Dżurak i S. Sikora, Warszawa 2000; J. Clifford, On Ethnographics Self-Fashioning: Conrad and Malinowski, in: Reconstructing Individualism: Autonomy, Individuality, and the Self in Western Though, ed. T. C. Heler, M. Sosna, D. E. Wellbery, Stanford 1986 (przekład polski M. Krupy w: Postmodernizm, op. cit.); G. Marcus, D. Cushman, Ethnographies as Texts, „Annual Review of Anthropology” 1982, vol. 1; J. Wiggins, Religion as Story, New York 1975; The Bible as Rhetoric, ed. by M. Warner, London 1990; J. Boyd, Heracles' Bow: Essays on the Rhetoric and Poetics of the Law, Madison 1985; B. S. Jackson, Narrative Theories and Legal Discourse, in: Narrative in Culture. The Uses of Story-telling in the Sciences, Philosophy, and Literature, ed. Ch. Nash, London and New York 1990; S. Fuller, Beyond the Rhetoric of Antitheory: Towards a Revisionist Interpretation of Critical Legal Studies, in: Rhetoric in the Human Sciences, ed. by H. W. Simons, London 1989; S. Fish, Doing What Comes Naturally: Change, Rhetoric, and the Practice of Literary and Legal Studies, Durham: Duke University Press 1989 (po polsku dostępna stąd rozprawa Praca $w$ tańcuchu: interpretacja $w$ prawie $i w$ literaturze, przel. M. Kilanowski, w: tegoż, Interpretacja, retoryka, polityka, red. A. Szahaj, Kraków 2002); D. McCloskey, The Rhetoric of Economics, Madison 1985 (po polsku dostępna 
przynależności tematycznej (przedmiotowej) jego analizy prowadzone były głównie metodami i narzędziami, w pojęciach i terminach wypracowanych w różnych odmianach literaturoznawstwa. Dostarczali ich zwłaszcza Arystoteles, Propp i Frye, rzadziej, ale także - strukturaliści (R. Barthes) i semiotycy $\mathrm{z}$ orientacji generatywnej (J. Greimas). Paradoksalnie: analizie nauki mieniącej się postmodernistyczną za wzór służyła nauka (głównie teoria literatury) modernistyczna (strukturalistyczna). Samo zresztą skupienie na tekstowym przedmiocie można uznać za efekt ubocznego oddziaływania modernizmu.

Z punktu widzenia literaturoznawstwa koncepcje narracyjnej natury poznania odwzorowującej się $w$ narracyjnej strukturze tekstu naukowego nie niosły rewelacyjnych odkryć. Uruchamiane w analizach rozpraw kulturo- i przyrodoznawczych dawne prawdy hermeneutyki i fenomenologii, strukturalizmu i semiotyki powtarzały wiedzę o tekście i kontekście wypracowaną przez badaczy literatury w 1 . połowie stulecia. Wiedza ta jednak odnosiła się do tekstu literackiego, nawet jeśli (jak w semiotyce) był on traktowany jako synekdocha tekstu kultury. Natomiast narratywiści (narratologowie?) przenieśli ją na tekst rozpoznawany dotąd jako naukowy. Wniosek był nietrudny do przewidzenia: tekstowi temu przypisane zostały własności (formy językowe i stylistyczne oraz kompozycyjne i gatunkowe) prototypowo rezerwowane dotąd dla tekstu literackiego. Dostrzeżony paralelizm w ich ukształtowaniu (szczególnie pod względem narracyjnym), nawet jeśli nie zawsze prowadził do przypisania wypowiedzi naukowej statusu wypowiedzi fikcyjnej, to przypisywał jej atrybuty takie, jakimi literaturoznawstwo modernistyczne obdarzało literaturę. Wypowiedź naukowa, pozbawiona transparencji wobec przedmiotu, który - jak modernistyczny tekst literacki - stracił status bytu niezależnego wobec świadomości i języka, zaczęła być rozpoznawana jako izomorficzna albo w stosunku do kulturowego (światopoglądowego, ideologicznego, aksjologicznego, w tym zwłaszcza etycznego) układu odniesienia, albo/i kategoryzacyjnej pracy umysłu. Wiedza, jaką wypowiedź ta niosła, miała więc charakter autoreferencjalny: efekt (tekstowy) poznania reprezentował warunki tego poznania, tzn. wzorce kultury lub/i uni-

tegoż autora rozprawa Gawędy ekonomistów z tomu Narrative in Culture. The Uses of Story-telling in the Sciences, Philosophy, and Literature, op. cit., przel. Z. Lapiński, „Teksty Drugie" 1991, nr 5); A. Kłamer, As if Economists and their Subjects were Rational, in: Rhetoric of Human Sciences, ed. J. Nelson and D. N. McCloskey, Madison 1987; J. Henkel, Linguistic Models and Recent Criticism: Transformational Grammar as Literary Metaphor, „PMLA” 1990, vol. 105, nr 3; W. J. Fisher, Human Communication as Narration: Toward a Philosophy of Reason, Value and Action, Columbia 1987; B. Gregory, Inventing Reality: Physics as Language, New York 1988; R. Harrè, Some Narrative Conventions of Scientific Discourse, in: Narrative in Culture, op. cit.; G. Myers, Making a Discovery: Narratives of Split Genes, in: Narrative in Culture, op. cit. 
wersalne schematy mentalne. Nie podlegala natomiast krytycznej refleksji sama zasada izomorfi (homologii, reprezentacji), przejęta w schedzie po modernizmie.

Diagnozy narracyjnego i naznaczonego ideologicznymi stygmatami charakteru poznania nie sięgały natomiast samych wypowiedzi diagnozujących. Pozostały one poza oglądem skierowanym na demaskowane z pasją (i talentem) tekstowe mechanizmy rządzące dyskursem naukowym. O ile dyskurs cudzy był dla narratologa transparentny, o tyle własny nie podlegał dostrzeżonym i wnikliwie opisywanym regułom ${ }^{20}$. Narratologicznie nastawione naukoznawstwo pozostało "filozofowaniem znikąd"21. Także pod tym względem powielało ono tryb odniesienia do przedmiotu znamienny dla modernistycznej teorii literatury - metajęzykowej w stosunku do obranego obiektu i apodmiotowej (gdy zaś ów ekskluzywizm bywał dostrzegany, wówczas najczęściej uzyskiwał rozwiązanie w odwołaniu do abstrakcyjnych, ahistorycznych wartości etycznych, które profetycznie obwieszczał ów patrzący znikąd podmiot).

Prawdopodobnie było to rezultatem między innymi faktu, że wbrew nazwie - skądinąd dalekiej od jasności, permanentnie wręcz wieloznacznej, od formalistów rosyjskich po kontynuujących ich poszukiwania strukturalistów francuskich - narratologia skupiała się nie na narracji, tak jak się ją tradycyjnie rozumie w poetyce, ale na poziomie, który nazwać by raczej należało fabułą 22. To Proppowskie "funkcje”, segmenty bądź moduły tworzące opowiadaną w tekście naukowym historię, i reguły ich łączenia ze sobą koncentrowały uwagę. Narracyjne (we właściwym sensie) ukształtowanie wypowiedzi, stosowane w niej strategie, typy narracji, punkt(y) widzenia mówiącego podmiotu (a zatem i jego odniesienie do przedmiotu) itp. nie wchodziło (do niedawna) ${ }^{23} \mathrm{w}$ pole

20 Nawet wtedy, gdy kolejni narratologowie demaskowali owe mechanizmy u poprzedników; por. np. W. B. Pearce, V. Chen, Etnography as Sermonic: The Rhetoric of Clifford Geertz and James Clifford, in: Rhetoric in the Human Sciences, ed. H. W. Simons, London 1989.

21 Przywoluje tym wyrażeniem rozprawe T. Nagela, The View from Nowhere, New York 1986 (przekład polski C. Cieślińskiej Widok znikq̨d, Warszawa 1997).

22 Zwracał na to uwage M. Głowiński, Narratologia - dzisiaj i nieco dawniej, „Teksty Drugie” 2001, nr 5 (przedr. w: Sporne i bezsporne problemy wspótczesnego literaturoznawstwa, op. cit.).

${ }^{23}$ Symptomatyczna pod tym względem może być antologia Narrative Dynamics. Essays on Time, Plot, Closure, and Frames, ed. by B. Richardson, The Ohio University Press 2002, w której przypomniane zostały klasyczne rozprawy o narracyjnym ukształtowaniu wypowiedzi od formalizmu po poststrukturalizm, w bogatszym zestawie niż zazwyczaj wykorzystywany $w$ narratologii powhite'owskiej. Podobny charakter ma też praca zbiorowa New Perspectives on Narrative Perspectives, ed. by W. van Peer and S. Chatman, New York 2001. Nader krytycznie o ograniczeniach narratologii z pierwszej fazy wypowiadała się również M.-L. Ryan, The Narratorial Functions: Breaking Down a Theoreti- 
zainteresowań. Jeśli już cokolwiek z powierzchniowego nośnika tekstu było nieobojętne, to jedynie poszczególne figury retoryczne (w pierwszej kolejności metafora), odnajdywane w tekście naukowym i mające zaświadczać o jego pokrewieństwie, jeśli nie o tożsamości, z tekstem literackim (bądź o pochodzącej od Vico jeszcze pierwotności myślenia poetyckiego ${ }^{24}$ ). To zaniedbanie narratologów, wywodzących się spoza literaturoznawstwa i tylko używających jego rozpoznań, nienawykłych do wnikliwej obserwacji subtelnych mechanizmów tekstu literackiego, odbiło się na ich własnym dyskursie, który trudno nazwać „naukowym pisarstwem”, „historią" bądź „opowieścią", choć sami tak je chętnie określają. Pisarstwo (cudze), jak ongiś „metoda”, pozostawało wyłącznie obiektem chłodnych analiz.

Pod tym względem sytuacja w literaturoznawstwie uznawanym za postmodernistyczne przedstawia się inaczej. Zwraca uwagę przede wszystkim to, że nie podjęło ono w zasadzie refleksji typu narratologicznego o własnym statusie dyskursywnym, a w każdym razie epidemia narratologiczna nie przybrała w nim rozmiarów pandemii ${ }^{25}$. Nie znaczy to, że narratologiczne rozpoznania pozostały niezauważone bądź zlekceważone ${ }^{26}$. Nie zostały tylko wyznawczo przejęte ani tym bardziej uznane

cal Promitive, „Narrative” 2001, vol. 9, nr 2 (special issue: Contemporary Narratology). W wymienionych pracach powtarza się przekonanie o istotnym dla dotychczasowych koncepcji narratologicznych zaniedbaniu - pominięciu ujęć zainicjowanych w latach 20., znanych pod nazwą point of view theory (przypomina je także M. Głowiński w przywoływanym poprzednio artykule, tym m.in. zaniedbaniem uzasadniając swój sceptycyzm wobec sukcesu narratologii $w$ humanistyce), odpowiedzialnych za ich trywialność. Daje się też zauważyć powrót, szczególnie w narratologicznie zorientowanym kognitywizmie, do wczesnych studiów nad narracją W. Labova. Jego, napisane wraz z J. Waletzkym, studium Narrative Analysis: Oral Version of Personal Experience (1967), nader formalne, skupione na jednostkach zdaniowych, zostało wręcz uznane za wzór dla dzisiejszych analiz (por. „Journal of Narratologie and Life History” 1997, vol. 7, nr 1-4; tu zwłaszcza artykuł J. Brunera, Labov and Waletzky Thirty Years On).

24 Takie stanowisko zaznacza się nie tylko $w$ znanych kognitywistycznych pracach o metaforze G. Lakoffa i M. Johnsona czy - w wersji jeszcze mocniejszej - w rozprawie M. Turnera, The Literary Mind. The Origin of Though and Language, New York Oxford 1996, ale też w wychodzących z zupełnie innych założeń rozważań $\mathbf{P}$. de Mana (por. jego Epistemologia metafory, w: tegoż, Ideologia estetyczna, przeł. A. Przybysławski, wstęp A. Warmiński, Gdańsk 2000).

${ }^{25}$ Nie pojawiły się np. prace o badaczach literatury jako pisarzach, nader liczne w odniesieniu do uczonych $\mathrm{z}$ innych dyscyplin (por. np. J. Boon, From Symbolism to Structuralism: Levi-Strauss and Literary Tradition, Oxford 1972; G. Beer, Darwin's Plot, London 1983; M. Bowie, Freud, Proust, and Lacan. Theory as Fiction, Cambridge 1987; S. E. Hyman, The Tangled Bank: Darwin, Marx, Frazer, and Freud as Imaginative Writers, New York 1962; G. Sh a piro, Nietzschean Narratives, Indianapolis 1989).

26 Negatywnych bądź sceptycznych opinii o narratologii pojawiło się względnie niewiele; z ważniejszych wymienić należy M. Głowińskiego (poza wymienionym artykułem także jego Poetyka wobec tekstów nieliterackich, w: tegoż, Poetyka i okolice, Warszawa 
za nowy „paradygmat”. Przenikały natomiast stopniowo do wnętrza dyskursu literaturoznawczego jako jeden z jego możliwych języków, jeden z naukowych światopoglądów, równie zasadny, jak i inne, i z całą pewnością nie uniwersalnie ważny. Wypowiedź literaturoznawcza po przejściach i „zwrotach” to bowiem wypowiedź, która wycofuje się z refleksji epistemologiczno-metodologicznej, ze śledztwa nad własnym statusem prowadzonego z poziomu metadyskursywnego, by wpisać tego typu refleksję w siebie. Narracyjna, fikcyjna i retoryczna natura poznania, jego wielogłosowość i wewnętrzna, wielopodmiotowa dramaturgia, stały się nie przedmiotem analizy, ale przedmiotem przedstawienia. Przedstawienia - także w sensie teatralnym: inscenizacji świadomie reżyserowanej i odgrywanej na oczach czytelnika, ujętej w - silnie niekiedy eksponowaną - ramę sceniczną ${ }^{27}$. To właśnie zdaje się odróżniać najmocniej literaturoznawczy dyskurs postmodernizmu od modernistycznego. Poszczególne języki-metody są w nim stosowane w funkcji prezentowanego obiektu, nie zaś w funkcji prezentującej. Przedmiotem tego dyskursu są relacje międzywypowiedziowe, zarówno między wypowiedziami uznawanymi za literackie, jak i literaturoznawcze: ich względność, dialog, w jaki wchodzą, ich moc sprawcza wobec wyznaczanego za ich sprawą przedmiotu, ich ideologiczne, etyczne, polityczne zaplecze i zobowiązania oraz właściwy im charakter performatywny.

Różnice dotyczą także podmiotu. W przeciwieństwie do podmiotu modernistycznego podmiot tego literaturoznawstwa jest wielojęzyczny. Nie przyjmuje żadnego z używanych języków za własny, dystansując się zarówno do nich, jak i do prototypów nauki oraz literatury (ich funkcji, celów, zobowiązań), które owe języki obudowały. W tym (ale tylko w tym) sensie można mówić o „literaturyzacji” literaturoznawstwa. Przedstawiając wielowymiarowość i niestabilność (niekonkluzywność) poznania oraz hipotetyczny status jego, fingowanego przez poszczególne języki odmiennie, przedmiotu, odwzorowuje ono typ poznawczego odniesienia do świata, jaki wypracowała literatura modernistyczna bądź, dokładniej, jaki zostal dla niej zawarowany, stając się jej wyłącznym przywilejem (bądź, z punktu widzenia modernistycznej nauki - skazą).

Taka, wpisana $\mathrm{w}$ teksty literaturoznawcze, dramaturgiczna konceptualizacja dyskursu literaturoznawczego, upodobnionego (podkreślić trzeba jednak raz jeszcze: niepowierzchniowo, nie na poziomie kompozycji, jak to przedstawia narratologia) pod względem poznawczym do dys-

1992; Nauka o literaturze wśród innych dyscyplin, w: Humanistyka przetomu wieków, red. J. Kozielecki, Warszawa 1999). Więcej polemik dotyczyło uznania wiedzy za fikcję (por. np. L. Cebik, The World is Not a Novel, „Philosophy and Literature” 1992, vol. 10, nr 1).

27 O „spektaklu teorii” pisała E. Bruss, Beautiful Theories. The Spectacle of Discourses in Contemporary Criticism, Connecticut and London 1982. 
kursu literackiego, ma ważne precedensy i antecedensy zarówno w modernistycznej literaturze, jak modernistycznej nauce o literaturze. Jej realizacje w literaturze stanowiły o wykształceniu się prozy (np. Karola Irzykowskiego) i poezji (np. Tymoteusza Karpowicza) autotematycznej. W nauce natomiast wyrażały się $\mathrm{w}$ przekonaniach o nieostrości granicy między nią a literaturą, podnoszących zawisłość projektów metodologicznych od badanych tekstów (formalizmu od futuryzmu, koncepcji języka poetyckiego i podmiotu lirycznego od liryki modernistycznej, literaturoznawstwa poststrukturalistycznego od afabularnej prozy autotematycznej). Szczególnie jednak mocno, wręcz normatywnie, tożsamość przedstawianego i przedstawiającego, tekstu literackiego i tekstu literaturoznawczego, podmiotu wypowiedzi i podmiotu wypowiadającego się 0 niej, były postulowane $w$ projekcie wywodzącym się jeszcze $z$ filozofii Bergsona, a żywym aż do lat 60 . - krytyki identyfikacji, wspartej na empatii i wczuciu, $\mathrm{z}$ wpisanym w nią obowiązkiem naśladowania dyskursu literackiego $\mathrm{w}$ literaturoznawczym, warunkującym doskonałe poznanie. Jednakże $\mathrm{w}$ krytyce $\mathrm{z}$ początku i połowy wieku akty wczuwania się $\mathrm{w}$ tekst, potwierdzone imitacją właściwego mu "stylu”, zmierzały finalnie do tożsamości z podmiotem autorskim - to "styl” twórcy (językowa ekspresja jego postrzegania świata) miał być powtórzony. Podmiot tekstu literaturoznawczego przyjmował tu zatem i odtwarzal jeden uprzywilejowany punkt widzenia - autora. Nie istniał między nimi żaden dystans; między „styl” autora a jego badawcze odczytanie i odbicie nie wkraczały inne języki pośrednie, inne podmiotowe punkty widzenia. Literaturoznawca $z$ końca stulecia, który rozpoznal nie-przedmiotowy, nie zewnętrzny wobec przyjętej perspektywy językowej status prezentowanego obiektu, tworzy jego (re)kreacje możliwe, świadomy różnicy wynikającej ze zrelatywizowania wobec przyjmowanych języków i - wobec nieistnienia dostatecznej racji wyboru między nimi - ich tymczasowości, niekonieczności i wymienności.

Najbliższy przekonaniom uznawanym za znamienne dla literaturoznawstwa postmodernistycznego o dyskursywnej tożsamości prezentowanego i prezentującego, tekstu literackiego i tekstu o tymże tekście, teorii i języka teoretycznego - byłby dyskurs M. Bachtina, W. Szkłowskiego, M. Heideggera, J.-P. Sartre'a, K. Burke'a i W. Benjamina. Nie przypadkiem to ich pisarstwo przeżywa w postmodernizmie intensywny renesans. Nie znajdowało się ono w centrum modernistycznego prototypu literaturoznawstwa, usytuowane raczej w tym jego nurcie, który - za Tynianowem - nazwać można „młodszą linią”. Niejasne co do swojej dyscyplinarnej przynależności, niepodatne na jednoznaczne zakwalifikowania, ono właśnie torowało drogę postmodernistycznej literaturze literaturoznawczej. Różnica między dawniejszym i nowszym pisarstwem 
teoretycznoliterackim polegałaby na wzmożonej i manifestacyjnie demonstrowanej świadomości uzależnienia przedstawianego od przedstawiającego oraz na wyciągniętych $\mathrm{z}$ tego rozpoznania konsekwencjach.

Konsekwencją pierwszą jest zmiana trybu wypowiedzi z monologowego na dialogowy, to znaczy równouprawniający współwystępowanie w jednej wypowiedzi rozmaitych języków, zarówno „nauki”, jak „fikcji”, języków „użytkowych” i „poetyckich”, poszczególnych wypracowanych dotąd języków „teoretycznoliterackich” i języków innych nauk (filozofii, psychologii, socjologii, kulturoznawstwa, a także języków nauk przyrodniczych). Języki te są przy tym przywoływane nie, jak dotąd, w trybie zapożyczeń lub poręcznych metafor terminologicznych, lecz $\mathrm{w}$ funkcji przedmiotu przedstawienia ${ }^{28}$. Konsekwencją drugą, nieodłącznie towarzyszącą polifonii dyskursu literaturoznawczego, jest przemieszczenie się jego podmiotu. Jego stabilne stanowisko zewnętrzne wobec prezentowanego obiektu, zakotwiczone w obranej mowie (reprezentującej określoną opcję metodologiczną, a zatem i światopoglądową) przesunęło się do wnętrza dyskursu i, przede wszystkim, zróżnicowało. Nie przypisane trwale do żadnego punktu obserwacyjnego, żadnej językowej perspektywy, nie dające się zdefiniować, proteuszowo zmienne - upodobniło się do stanowiska zajmowanego przez podmiot wypowiedzi dramatycznej29. Podobnie jak w niej, głos podmiotu tekstu literaturoznawczego został rozpisany na szereg równoprawnych głosów podmiotów wewnętrznych ${ }^{30}$. O ile tylko w przypadku dramatu literackiego sytuacja wypowiedzi jest fikcjonalna, a jej przedmiot - fikcyjny, o tyle w dramaturgicznej narracji literaturoznawczej ma ona charakter niefikcjonalny. Niefikcyjny (wtórnie intencjonalny, jak zostało to nazwane na początku) jest też przedmiot odniesienia. Dlatego, jak można sądzić, literaturoznawcy coraz częściej odsłaniają biograficzne zakorzenienie swojego pisarstwa, jego doświad-

28 Znamienny pod tym względem jest tom After Poststructuralism. Interdyscyplinarity and Literary Theory, ed. N. Easterlin, B. Riebling, Evanston 1983. Ostra dyskusja, jaka się wokół niego rozegrała, zainicjowana krytyką A. Sokala (A. D. Sokal, J. Bricmont, Fashionalbe Nonsense: Postmodern Intellectuals' Abuse of Science, Picador 1998), do której przylączył się także S. Fish (w Proffesional Correctness, op. cit.), wydaje się efektem niezrozumienia intencji autorów wystąpień zamieszczonych w tomie, którzy nie zmierzali do typowej dla modernizmu aplikacji osiągnięć nauk ścisłych do literaturoznawstwa, lecz do ich przedstawienia właśnie jako możliwych literaturoznawczych języków.

$29 \mathrm{Za}$ fazę wstępną tego procesu dramaturgizacji można uznać prace przedstawiające jeden tekst literacki z punktu widzenia i w języku poszczególnych propozycji teoretycznych, takie np. jak F. Crewsa The Pooh Perplex, London 1987 czy w Polsce „Panny $z$ Wilka" Jarostawa Iwaszkiewicza, red. I. Iwasiów i J. Madejski, Szczecin 1996.

30 Znamienna pod tym względem jest droga pisarska Witkacego - od filozoficznego monologu do dramatycznego (i powieściowego) dialogu; problem ten podjął ostatnio J. Błońs ki, Od Stasia do Witkacego, część druga: Witkacy. Sztukimistrz. Filozof. Estetyk, Kraków 2000. 
czeniowe, emocjonalne, cielesne, spacjalne i temporalne parametry. Biografika poznania naukowego, traktowana nie jako ewentualny kontekst wyjaśniania i legitymizacja wyborów, lecz kontekst odkrycia, wyparła wręcz w niektórych przypadkach logikę poznania; bios zastąpił logos.

By podsumować: narratologia, która zdominowała rozpoznania specyfiki wypowiedzi naukowej w licznych dyscyplinach wiedzy o społeczeństwie i kulturze, a która nie odniosła naukowego sukcesu w literaturoznawstwie, choć jemu była najbliższa, pomijała z reguły jej aspekt podmiotowy. Zainteresowana schematami kompozycyjnymi, odtwarzającymi wzorce argumentacji, przejmując modele narracji ( $w$ istocie zaś kompozycji fabuły) od Arystotelesa, Frye'a i Proppa i uznając ich determinujące oddziaływanie, traktowała analizowane teksty jako albo anonimowe, albo jednogłosowe, pozostające $\mathrm{w}$ relacji metonimicznej $\mathrm{w}$ stosunku do wzorców kultury i/lub pracy umysłu. Zapewne zadecydował o tym także fakt, że wzorowała się na badaniach nad tekstami pozbawionymi autorstwa (jak mit i bajka), a za punkt odniesienia obrała takie, w których podmiotowość była świadomie neutralizowana, zaś jej przejawy uchodziły za skazę, tzn. teksty zgodne z - opisanym przez Kuhna prototypem „nauki normalnej”. Wreszcie - że $\mathrm{z}$ uwagi na przedmiot swojego odniesienia zajmowała stanowisko zasadniczo realistyczne, uznając, iż za tekstami, które brała pod uwagę, kryje się niezależna lub uniezależniona od świadomości rzeczywistość społecznych, historycznych i kulturowych „zdarzeń”. Dla literaturoznawcy „zdarzeniem” jest jednak wypowiedź, której istnienia niezależnego od podmiotu, zarówno kreującego, jak (re)kreującego, można bronić jedynie na gruncie założeń esencjalizmu (przede wszystkim założenia o istnieniu intersubiektywnych i transsubiektywnych reguł językowej komunikacji), które same stały się problemem.

Po drugie - narratologia arbitralnie przyjęła do wiadomości linearny i teleologiczny model poznania i związaną z nim monologową (jednogłosową) koncepcję świadomości. Tymczasem, jak wynika z nowszych badań nad naturą umysłu i jego pracy poznawczej, formę narracyjną (sekwencyjną) należałoby raczej uznać jedynie za powierzchniowe uporządkowanie wyników poznania, dokonywane przy ich komunikowaniu, nie zaś za reprezentację samych poznawczych procesów, a przy tym formę nie jedynie możliwą. Obok prezentacji narracyjnej badacze odnajdują także prezentację typu poetyckiego, wspartą na metaforze, a nie metonimii ${ }^{31}$. Nawet jeśli pominąć typ poznania metaforycznego i poprzestać na metonimicznym, to $i$ tak przedstawiany $w$ narratologii model poznania naukowego będzie ściśle odpowiadać fabule mitu, noweli i bajki, na których

31 O obu modelach komunikacji wyników poznania patrz: D. McCloskey, op. cit. 
podstawie został wypracowany. Model ten, temporalny, kauzalny i teleologiczny, odwzorowuje nie złożony proces rozumienia, lecz jego wytwór: akt wyjaśniania procedur poznawczych, w których wytwór ten powstał. Nie ma powodu, by przy nim obstawać, tym bardziej że w refleksji nad procesami poznawczymi zachodzącymi w umyśle i ich językową reprezentacją wyraźnie zdobywa przewage model poznania spacjalnego i symultanicznego, „amalgamatowego" 32 , wielogłosowego, wieloperspektywicznego i wewnętrznie zdialogizowanego - poznania, które literaturoznawstwo prototypowo powiązało właśnie $\mathrm{z}$ wypowiedzią dramatyczną (bądź, w języku Bachtina, polifoniczną). Nie ma ono charakteru sekwencyjnego ani przyczynowo-skutkowego przebiegu i nie zmierza definitywnie do jednoznacznego celu ${ }^{33}$. Wydaje się, że właśnie tego typu poznanie konceptualizowała literatura uznawana za modernistyczną ${ }^{34}$. Takie też jest prezentowane $\mathrm{w}$ tekstach literaturoznawczych, które się nią posiłkują: używają znamiennego dla niej form monologu wewnętrznego i mowy pozornie zależnej, szczególnie reprezentatywnej dla wielopodmiotowości, operują strategiami intertekstualnymi i interdyskursywnymi, stosują amorficzną (sylwiczną) kompozycję, wprowadzając gatunki dialogu i wywiadu, fragmentu i brulionowego notatnika, rozbudowują w autonomiczny tekst przypisy ujawniające podskórny wielogłosowy polilog, posiłkują się epigrafami i metaforyczno-retorycznymi tytułami i podtytułami bądź odsyłającymi do literatury sygnałami gatunkowymi, przekształcają najtrwalej bodaj zrośnięte z narracyjnym poznaniem monologowym, najbardziej konserwatywne gatunki encyklopedii i słownika.

Jest osobną sprawą, czy są one symptomatyczne dla formacji postmodernistycznej, czy też tylko za takie je uznajemy.

32 O tego typu poznaniu, a dokładniej - pracy umyslu piszą G. Fauconnier i M. Turner, The Way We Think. Conceptual Blending and the Mind's Hidden Complexities, New York 2002 (tu też pojęcie „amalgamatów konceptualnych”, jak proponuje tłumaczyć „conceptual blendings" J. Płuciennik w przywolywanej pracy) oraz G. Lakoff i M. Turner, Philosophy in the Flesh. The Embodied Mind and Its Challenge to Western Thought, New York 2002. Również badania nad językiem niewerbalnym (migowym), eksponujące równoczesność i spacjalny (,sceniczny”), a nie temporalny, przebieg procesów mentalnych, dostarczają argumentów podważających uniwersalny charakter narracyjnego rozumienia. W przypadku ludzi głuchych od urodzenia, którzy nigdy nie mieli kontaktu z temporalnym, $\mathrm{z}$ istoty swojej linearnym językiem werbalnym, procesy te znajdują szczególnie silną reprezentację komunikacyjną (por. L. Petitto, U. Bellugi, Spatial Cognition and Brain Organisation, in: Spatial Cognition, ed. J. S. Davis, M. Kritchevsky, U. Bellugi, Hour - London 1988; O. Sakcs, Zobaczyć glos. Podróż do świata ciszy, przeł. A. Małaczyński, Poznań 1998).

$33 \mathrm{O}$ algorytmicznym charakterze sekwencyjnego modelowania procesów poznawczych przebiegających w istocie synchronicznie patrz: J. M. Groh i M. S. Gazzaniga, How the Brain Keeps Time, „Daedalus”, Spring 2003.

$34 \mathrm{O}$ dramaturgicznym modelu poznania literackiego por. R. Schusterman, Art as Dramatisation, „Journal of Aesthetics and Art Criticism” 2001, vol. 59, nr 4. 
Wypowiedź jest prawdziwa, jeśli jej zdania są prawdziwe przynajmniej w jednym świecie możliwym wobec aktualnego - głosi podstawowa teza teorii światów możliwych ${ }^{35}$. Podobne uprawomocnienie wnosi wnioskowanie przez abdukcję ${ }^{36}$. Korzystając $\mathrm{z}$ tych legitymizacji, za przedmiot dalszej analizy (zestaw perswazyjnych argumentów) można by obrać np. rozprawę Douglasa R. Hofstadtera Godel, Escher, Bach: an Eternal Golden Braid lub Josepha Hillisa Millera Ariadne's Threat. Story Lines, Wystepek Michała Pawła Markowskiego lub Szczeliny istnienia Jolanty Brach-Czainy, powieść Umberto Eco Imię róży lub powieść Mieczysława Porębskiego $Z$., bądź z wcześniejszej modernistycznej „młodszej linii" - ZOO, czyli Listy nie o milości Wiktora Szkłowskiego lub pisma Kennetha Burke'a z tomu Perspectives by Incongruity, by wyliczyć niewymieniane dotąd przykłady37. Jeśli wybieram trzy polskie wypowiedzi literaturoznawcze: powieść („metapowieść historiograficzną”) Anieli Gruszeckiej o kronice Galla Anonima, „przepowieści” Krzysztofa Rutkowskiego Kościót świętego Rocha i fragment powieści Włodzimierza Boleckiego $C_{h a c k}{ }^{38}$, to $\mathrm{w}$ przekonaniu, że, choć trudne jeszcze do uznania za „fakty naukowe”, tym bardziej że w przypadku Rutkowskiego i Boleckiego wciąż nie gotowe, niemniej jednak wydają się one reprezentatywne dla ewolucji od narrarcyjnej do dramaturgicznej koncepcji dyskursu literaturoznawczego. Łączy je nadto, co istotne, tematologiczna przynależność do wspólnej odmiany wypowiedzi historycznoliterackiej. Nie-

${ }^{35}$ Bardzo mocno wypowiada to, mające jeszcze konwencjonalistyczny rodowód, przekonanie L. Nowak: "Nauka jest niezdolna do wymyślenia tezy, która nie jest prawdą w jakimś świecie. Co najwyżej może to być prawda dla nas nieużyteczna", por. tegoż, Pozarealizm $i$ antyrealizm $w$ rozumieniu nauki, w: $O$ nauce $i$ filozofii nauki, red. $\mathrm{K}$. Zamiara, Poznań 1995.

36 Wnioskowania abdukcyjne w literaturoznawstwie szczególnie mocno forsuje U. Eco; por. m.in. tegoz, Horns, Hooves, Insteps: Some Hypothesis on Three Types of Abduction, in: The Sign of Three: Dupin, Holmes, Peirce, ed. by U. Eco, T. Sebeock, Bloomington 1983.

37 D. R. Hofstadter, Godel, Escher, Bach: an Eternal Golden Brain, Sussex 1979; J. Hillis Miller, Ariadne's Threat. Story Lines, New Haven and London 1992; M.P. Markowski, Wysteppek. Eseje o czytaniu i pisaniu, Warszawa 2001; J. Brach-Czaina, Szczeliny istnienia, Warszawa 1992; U. Eco, Imię rózy, przeł. A. Szymanowski, Warszawa 1988; M. Porębski, Z. po-wieść, Warszawa 1989; W. Szkłowski, ZOO, czyli listy nie o miłości, przeł. M. Jagiełło, „Literatura na Świecie” 1986, nr 8; K. Burke, Perspectives by Incongruity, ed. by S. E. Hyman with the assistance of B. Karmiller, Bloomington 1964.

38 A. Gruszecka, Powieść o kronice Galla, cz. 1, t. 1-2, Kraków 1962; cz. 2, Kraków 1962; cz. 3, t. 1, Kraków 1964, t. 2. vol. 1, Kraków 1966, vol. 2, Kraków 1970; K. Rutkowski, Kościót Śsiętego Rocha: przepowieści, Warszawa 2001; W. Bolecki, Chack, w: Maski wspólczesności. O literaturze i kulturze XX wieku, red. L. Burska i M. Zaleski, Warszawa 2001 (cytaty według tych wydań oznaczane numerem strony w tekście). 
przypadkiem chyba innowacyjna, dramaturgiczna koncepcja literaturoznawstwa kształtowała się (podobnie zresztą jak narratologia, która rodziła się w refleksji historiograficznej) na obszarze historii literatury, najbardziej bodaj spornym i najmocniej zachwaszczonym od końca XIX wieku, wyjątkowo obciążonym naukowymi, metodologicznymi i ideologicznymi stereotypami. Współczesna, krystalizująca się już od lat już 60., polska proza historycznoliteracka wydaje się skupiać w sobie całą drogę przemian od literaturoznawstwa narracyjnego do dramaturgicznego.

Powieść Gruszeckiej, pisana prawie przez dziesięć lat (1962-1970), gdyby nie to, że powstała wcześniej, niż rozpoczęła się polska kariera Haydena White'a, byłaby zapewne odczytywana jako ilustracja jego koncepcji, a nawet przenikliwa krytyka jej złudzeń. Nic jednak nie wskazuje na to, że autorce znane byly prace autora Metahistory ani inne podobne interpretacje historiografii, także polskie, wypracowywane w czasie pisania utworu (Arthura Danta, Louisa Otto Minka, Michaela Serresa, J. Pomorskiego). Rzecz jednak nie w tym, by podnosić jej prekursorstwo bądź po raz kolejny zastanawiać się nad wtórnością wiedzy naukowej wobec artystycznej. Warto raczej podkreślić, że u Gruszeckiej, powieściopisarki i badaczki powieści, oba typy poznania, naukowego i artystycznego, wchodzą w związek bezpośredniej i ścisłej zależności.

Powieść o kronice Galla to obszerny, trzyczęściowy, pięciotomowy utwór historyczny w siedmiu woluminach, którego bohaterką jest historia odczytań tekstu uznawanego za historyczny - tytułowej kroniki Anonima. Z odczytań tych, zrekonstruowanych w trybie fikcji powieściowej, a sięgających czasów pierwszych pogallowych kronikarzy-ideologów władców piastowskich po uczonego z okresu międzywojennego, Tadeusza Wojciechowskego, wyłania się koncepcja historiografii jako poznania o charakterze opowieści, uwikłanej w relacje władzy, religii, polityki, nauki, prywatnych urazów i ambicji. Autorka nie zmierza jednak ani do podważenia relacji o przeszłości, ani do odnalezienia jednej „prawdy” o niej, ani nawet do demaskacji narracyjności historiografii, lecz do przedstawienia wielości prawd możliwych. Ukazuje, że wydarzenia podawane jako obiektywne fakty przez kolejnych narratorów, którym udziela samodzielnego głosu, są w zasadzie te same, co u Galla Anonima, ale $\mathrm{w}$ rezultacie ich rekonfiguracji, przemieszczeń $\mathrm{w}$ hierarchii ważności, przesunięć i pominięć, stają się odmiennymi „faktami” tekstowymi.

Gruszecka wyeksponowała, oczywiście, relatywizm wiedzy historycznej i jej literacki charakter (literacki, bo sama Kronika Galla została potraktowana jako tekst literacki, a nie transparentny dokument historyczny), wiedzy zależnej od pozycji pisarza w układzie odniesienia, w którym tworzy, i zamierzonych przez niego oraz jego mecenasa (instytucje dworskie, religijne i naukowe) celów perswazyjnych. Kolejne 
(re)konstruowane $\mathrm{w}$ utworze fabuły o czasach fabularnie przedstawionych przez kronikarza wypełniają zdarzenia związane ze zmieniającymi się w dziejach „interesami”. Dla odbiorcy próbującego dociec „prawdy” o przeszłości pozostają one poznawczo niedostępne bez uwzględnienia tych kontekstów. Odbiorcy współczesnemu (czytelnikowi modelowemu Gruszeckiej) pozostaje zaś uznać je wszystkie za prawdziwe, acz prawdziwe względnie, a prawdę zidentyfikować $\mathrm{z}$ wielością prawd alternatywnych, już to krzyżujących się ze sobą, już to równoległych i niesprowadzalnych do siebie, jednakowo usprawiedliwionych i jednakowo nieostatecznych. Powieść przekonuje go, że im więcej takich prawd zna, tym większą wiedzą dysponuje; im lepiej potrafi osadzić je w kontekście wyjaśniania, zdemaskować ich genezę, zlokalizować perspektywę pisarza, tym pełniejsze poznanie osiąga i tym bardziej uodparnia się na jego moc perswazyjną.

Intencja autorki wydaje się więc pokrywać z przekonaniami narratologicznie zorientowanych historiografów. Podobny też (na pozór) przyświeca jej cel. Projektowana w jej powieści koncepcja wiedzy historycznoliterackiej jako mającej znamiona fikcji opowieści o dziejach konstruowania własnego przedmiotu może być interpretowana $\mathrm{w}$ kategoriach etycznych - jako służebna wobec celów emancypacyjnych: uwolnienia badacza od zobowiązań ideologicznych, wiązania się z zawsze interesownymi światopoglądami (wielkimi narracjami), patrzącego zatem na nie wszystkie z pozycji ekskluzywnej świadomości liberalnej. Podmiot prowadzący narrację w powieści Gruszeckiej jest jednak podmiotem fikcji, nadto zaś nie zajmuje pozycji auktorialnej. W przeciwieństwie do podmiotu opowieści historiografów-narratologów, którzy głosząc relatywizm poznania historycznego, sami nie podlegają demaskowanym prawom, prowadzi wielogłosową narrację personalną i nie wyłącza własnego stanowiska poznawczego $\mathrm{z}$ pola ich oddziaływania.

Gruszecka napisała bowiem powieść, a nie rozprawę mieszczącą się w ramach dyskursu naukowego (metodologii czy filozofii nauki), typową zresztą powieść historyczną, której fabuła swobodnie miesza Dichtung i Wahrheit, gdzie realne postacie zostają umieszczone w fikcyjnych sytuacjach, gdzie nawet ich rozmowy toczą się w fikcyjnym języku (jak u Sienkiewicza, jej średniowieczni bohaterowie mówią polszczyzną stylizowaną archaicznie na język XVII wieku, choć żona dialektologa i historyka języka, Kazmierza Nitscha, mogłaby zapewne nie modernizować ich wypowiedzi). Fikcyjność opowieści zmienia zaś zasadniczo dyskursywny status wpisanych w utwór przekonań o naturze poznania historycznego; także i one stają się fikcjami, a nie prawdami, którym można by przypisywać wartość obligatoryjnych konkluzji. Innymi słowy, wybierając ramę 
modalną literatury, Gruszecka uniknęła antynomii, które obciążają narratologię typu White'owskiego.

Gruszecka nie pytała jeszcze o dokumenty relacjonowane $\mathrm{w}$ trybie fikcji. Przekształciła w zdarzenia powieściowe te tylko teksty, które historycy dziejów politycznych uznawali za źródła godne wiary, ale, podobnie jak oni, nie zakwestionowała ich wyłączności. Stworzyła z nich wprawdzie wielogłosową, epicką opowieść, wyczerpującą jednak tylko usankcjonowane (i, co oczywiste, dostępne dla niej) tekstowe ujęcia przeszłości. I choć jej narracja pozwala domniemywać, że przetrwały one w pamięci historycznej wyłącznie $\mathrm{z}$ racji związanej $\mathrm{z}$ nimi wartości światopoglądowej, niemniej jednak nie daje podstaw do domyślania się istnienia innych, takich, których archiwa nie dochowały się, które zostały zmarginalizowane lub usunięte.

Pytanie o to, co historia literatury wyparła, do czego - z różnych względów - nie chciała się przyznać, co utajniła, jest natomiast centralne dla badaczy prozy historycznoliterackiej o rodowodzie Foucaultowskim. W literaturoznawstwie polskim ma ono dwóch wybitnych przedstawicieli: Jarosława Marka Rymkiewicza i, kontynuującego jego zamysł, (zarówno w sensie tematycznym, jak stylistycznym) Krzysztofa Rutkowskiego. Proza Rutkowskiego dystansuje się przede wszystkim do faktów przywoływanych w prototypowych rozprawach z zakresu historii polskiej literatury romantycznej, tych zwłaszcza - choć nie wyłącznie - którym przypisany został status naukowy. Ironizując nad stosowanymi w nich schematami fabularnymi (to jest wzorcami argumetacji i dowodzenia), dopisując do nich tekstowe zdarzenia pomijane, Rutkowski buduje na nich opowieści alternatywne wobec oficjalnych. W opowieściach tych ważne są mikroślady przeszłości - zarówno te, które zostały unieważnione wobec uznania ich za nieważkie, a które dla autora Kościoła Świętego Rocha są równorzędne ze śladami wyraźnie odciśniętymi w dziejach, jak te skrzętnie ukryte $\mathrm{w}$ archiwach i równie skrzętnie "zapomniane" przez badaczy, jak te nawet, których poświadczenie trudno znaleźć, a jednak powinny były istnieć i dla których miejsce zostało przewidziane przez opowieści wcześniejsze. Z odzyskiwanych i dopowiadanych zdarzeń tekstowych pod piórem pisarza-historyka literatury powstają opowieści typu zagęszczonego (thick description), posługujące się techniką soczewki i retoryką synekdochy. Rutkowski nie ukrywa ich fikcyjnego charakteru; przeciwnie - manifestacyjnie go podkreśla, przypisując zarazem fikcji funkcję prawdy donioślejszej niż ta, którą można zweryfikować (stąd ich nazwa gatunkowa, łącząca opowieść z przepowiednią i przypowieścią: „przepowieść”).

Konstruowane $\mathrm{w}$ trybie domysłu i traktowane jako konieczne dopełnienia obrazu przeszłości, bez których byłby on niekompletny i nieciągły, 
„przepowieści” przedstawiają zarazem mechanizmy rządzące pamięcią o niej. Są przecież ponad wszystko „przypowieściami”, przypowieść zaś, zgodnie $\mathrm{z}$ naturą gatunkową, wymaga interpretacji alegorycznej. Wzorem niektórych postulatów Haydena White'a i Franklina Ankersmita, Freudowskich wątków w historiograficznych refleksjach Derridy oraz praktyki historycznoliterackiej Harolda Blooma, Rutkowski naświetla te mechanizmy nie $\mathrm{z}$ socjokulturowego, jak Gruszecka, ale psychoanalitycznego punktu widzenia. Procedury stłumienia i wyparcia odgrywają według niego istotniejszą rolę $\mathrm{w}$ przeformułowywaniu zdarzenia tekstowego na fakt naukowy niż sankcje narzucane przez światopoglądy polityczne bądź naukowe.

Demaskowanie „fałszywej świadomości” badaczy dziejów sztuki literackiej jest głębokim tematem przepowieści. Zagęszczony opis tekstowych zdarzeń faktycznych i możliwych, pieczołowicie rekonstruowanych i starannie (także w warstwie stylistycznej) konstruowanych - to tylko ich powierzchnia. Punkt widzenia autora jest wprawdzie jawny (jawna jest także sytuacja narracyjna): jego głos lokuje się jednoznacznie po stronie historii literatury alternatywnej, ale zarazem $w$ jego narracji brzmią głosy adwersarzy. W dialogu z nimi Rutkowski zajmuje stanowisko parodysty: ironizuje nad ich epistemologicznymi złudzeniami (obiektywizmem, weryfikacjonizmem, stosowaną logiką argumentacji, indukcjonizmem), wyszydzając bezwzględnie konkluzje, które $\mathrm{z}$ całą powagą glosiły $\mathrm{w}$ majestacie autorytetu instytucji naukowych. Na przykład takie:

Członek Polskiej Akademii Umiejętności [...], rozpatrzywszy na posiedzeniu Komisji Antropologii i Prehistorii niektóre szczegóły budowy czaszki [Słowackiego - D. U.] [...], wykazal asymetrię oczodolów oraz stwierdził większy rozwój lewej strony lewej skroni [...]. Następnie, celem rozpoznania rasy, autor ów porównal typ Słowackiego $\mathrm{z}$ wynikami dawniejszych swych badań nad typem szlachty polskiej na Ukrainie [...] i wykazał , że istnieje między nimi antropologiczne pokrewieństwo. [...] Te cechy każą szukać jakiejś przymieszki. Na myśl szukania naprowadził [...] prof. Kleiner, tłumaczący [...], że w utworach Juliusza tkwi wiele pierwiastków zaczerpniętych ze Wschodu. Cechy antropologiczne wskazują na możliwość rasowego pokrewieństwa Slowackiego z Ormianami (s. 245).

Kpiąc i parodiując, posługując się cytatem lub aluzją, parodiowane rozpoznania Rutkowski jednak przywoluje. Bez ich uobecnienia jego własna opowieść pozostawałaby nieczytelna.

Dogmat scjentyzmu nie zostal przy tym w przepowieściach zamieniony na dogmat antyscjentyzmu, jedna wielka narracja (naukowa) zastąpiona inną (literacką). Przepowieści należą równocześnie do literatury i do nauki o literaturze. Parodiują prototypową historyczną wiedzę 
literaturoznawczą w trybie uznawanym za literacki, przedstawiają ją przy użyciu bogatego repertuaru chwytów retorycznych wiązanych prototypowo $\mathrm{z}$ nauką o literaturze, zachowując dla siebie status opowieści możliwej, która nie pretenduje do wyparcia poprzednich. Zachowuje je, przenosząc tylko do rzędu niekoniecznych, nieobligatoryjnych, a jeśli prawdziwych, to nie w mocniejszym sensie niż ona sama.

Fragment powieści Włodzimierza Boleckiego Chack stanowi parodię wielostopniową, dystansującą się zarówno do prototypowych wersji oficjalnej historycznej wiedzy o literaturze, jak komplementarnych wobec nich, zrelatywizowanych socjologicznie, kulturowo i psychoanalitycznie wielogłosowych opowieści alternatywnych. Chack, napisany prawie w całości w trybie przypuszczającym bądź pytajnym, nie opowiada się za żadną z nich. Co więcej, nie tylko je parodiuje, lecz także własną opowieść, zastrzegając często $\mathrm{w}$ udawanej bezradności „powinienem napisać [...] ale nie wypada" i jednak pisząc to, czego pisać - wobec już skonwencjonalizowanych stylów obu narracji historycznoliterackich, dawnego i nowego - nie wypada. Bolecki-pisarz, wyposażony $w$ profesjonalne kompetencje historyka i teoretyka literatury, powstrzymuje się przed zajęciem stanowiska po którejkolwiek stronie. Jego ironiczna i autoironiczna narracja pozostawia czytelnika w stanie permanentnej wątpliwości, co z przywoływanych $\mathrm{w}$ niej argumentów należy tylko do zdarzeń tekstowych, a co do rzeczywistych faktów, które z nich ujęte są ramą literacką, a które przytoczone serio. Jak w hypallage i syllepsie, autor zamyka je w jednym zdaniu, odsłaniając w licznych odautorskich interwencjach reguły prowadzonych gier i mimo to prowadząc je nadal. Jego własne stanowisko pozostaje w sferze nierozstrzygalników. Sygnowane przez gramatyczne ,ja”, płynnie przechodzi w inkluzywne „my”, by zaraz potem zdepersonalizować się, zniknąć wśród bezosobowo przywoływanych ciągnących się w nieskończoność przyczynkarskich informacji źródłowych, typowych dla podmiotu wiedzy (nie wiadomo tylko: informacji rzekomych czy prawdziwych, co autor z humorem podnosi: „że czy nie łże, musimy mu wierzyć”).

$\mathrm{Na}$ to więcej niż podwójne, wielostopniowe kodowanie naprowadza w Chacku figura amplifikacji. Zasadza się ona na hiperbolicznych enumeracjach, wyostrzając uwagę na retoryczne powtórzenia, paralele i kontrasty, które, gdyby nie owo spotęgowanie, mogłyby zostać zapisane na rachunek emfatycznego uczonego-historyka starego stylu. Pisarza-historyka nowego stylu, miłośnika opisu zagęszczonego i mikroanegdoty, demaskują z kolei stylizacje na argumenty, którymi ów chętnie się posługuje, nakładając jedną fikcję na inną. Konstruując opowieść biograficzną o zagubionym w mrokach historycznej niepamięci tytułowym Chacku (vel Ignacym Chaćkiewiczu), Bolecki parodiuje więc praktyki naukowe 
historycznoliterackiego pisarstwa psychoanalitycznego: „Holm kwituje tę sprawę jednym, ale wystarczającym zdaniem: «rzyć mu bykowcem obili». Nie najlepiej świadczy to o naukach rodzicielskich ojca Chacka, ale trudno coś więcej powiedzieć. Po prostu rzyć mu obili i żyć mu się odechciało" [s. 112].

Opowieść o Chacku, podobnie jak powieść Gruszeckiej i „przepowieści" Rutkowskiego, należy do fikcji literaturoznawczych. Mają one charakter nie mimetyczny, ale diegetyczny: prezentują wzory przedstawiania naukowego, obowiązujące globalnie (Gruszecka, Rutkowski) lub lokalnie (Bolecki) w tzw. modernistycznej i tzw. postmodernistycznej historii literatury. Fikcjonalizując te języki - światopoglądy poznawcze, czyniąc je obiektem przedstawienia, zarazem je krytycznie weryfikują. Sytuując zaś własne przedstawianie po stronie dyskursu wiązanego z literaturą - podważają jednocześnie same siebie.

Przy okazji przywracają poznawczą i ideową nośność samej literaturze, tak problematyczną dla literaturoznawstwa modernistycznego, które uprzywilejowało własne poznanie jej kosztem. Ale podważając uzurpacje tego literaturoznawstwa do zmonopolizowania wiedzy o przeszłości, przywołują jednocześnie te jego fragmenty, w których wiedza ta nie wchodziła w konflikt $\mathrm{z}$ pisarstwem - wielogłosową, polifoniczną, interdyskursywną prozę naukową Szkłowskiego i Tynianowa, Bachtina i Benjamina, Heideggera, Sartre’a i krytyków genewskich. Inspirują tym samym do rewizji i naszej postmodernistycznej moderny, i modernistycznej postmoderny ${ }^{39}$.

39 Tak rzecz nazywając, odwołuję się do rozważań $\mathrm{W}$. Welsch a z Unsere postmoderne Moderne (1987; przekład polski R. Kubickiego Nasza postmodernistyczna moderna, Warszawa 1998). 